Kohl: a Journal for Body and Gender Research

Vol. 6, No. 1 (Summer 2020)

\title{
Why the Good White People Should Not Ask Me If I'm Staying Safe
}

\author{
Zahra Zuwayed
}


Safe from what?

Are we safe from the news on our screens, or the lightness of our skins? I'm brown, you are white: two good hearts, but. Two non-Black people asking each other if we're staying safe. There's something seriously wrong with why we choose not to address the not-us part of the equation. Who is us? Who is not-us?

I'm a brown woman: a woman of color, PoC, a woman, (being a woman is always bad). A GCC (Gulf Council Countries) national, AShAB (assigned Shia at birth), an other, bullied for something I never understood. An identity I was draped with as early as the veil covered my face in fourth grade.

My cousin Ali and I were born a few days apart, both brown. They said our mothers drank chocolate milk while pregnant with us. When my skin was dry my arm would look like wood bark. I hated my skin because its darkness was always ridiculed and I often rubbed Fair \& Lovely cream to whiten it. My skin is still dark.

Ali's older brother was very white. The family called him "The American," while Ali was "The Indian." I was too young to remember why Arab boys who spoke no English learned to call whiteness "American." And we cannot talk about racism in GCC without talking about the exploitation and dehumanizing of expat workers, especially Indians.

***

I'm in "America" now. And "American" has different shades and different languages in inconvenient neighborhoods and seminar papers. In "America," white people assume I'm Indian, because Americans love to box people in categories together. I relate to that dehumanizing because to this day, my body is a problem. Visibility can be fatal for a "traditional" Arab Muslim woman. And just because I smile in Karen's selfie doesn't mean that a smile could not have my teeth smashed or my fearful heartbeats stopped. I know what it means to be hyper aware of your body and to count the visible parts and limbs and which street or platform to step on. Hyper awareness is a violent component of silencing. "So how does it feel like being a Saudi woman in America?" asks John. "Do you feel oppressed?"

White people are not used to not having an "other" body whose appearance will always be offensive to someone.

An armed man at a check point in Saudi told me I must cover my face in my photo ID because it offended him. I started covering my photo ID with a sticky from the pile I used for homework assignments. My Sudanese colleague told him, "we teach your sisters and daughters. You shouldn't treat us like this." That's how the oppressor might humanize the oppressed. 
We have a limited capacity for pain; when that pain tolerance is maxed out, the remaining trauma never goes away. That is the core of oppression I want white people to understand. Being aware of your body will most likely traumatize you; it will make you incapable of loving your body because you're too busy being afraid. Love and fear cannot exist in the same vicinity, and to untangle the core of these oppressions is a lot of work.

In 2017, I was depressed and at a conflict with my body. I decided I needed to let go of it. That I must return it as it is not mine. That I was tired of carrying it and trying to understand why it is so offensive. Arab and Muslim women being sold into marriage like transferring property can be a hot topic for your undergraduate research paper, but it is a reality for people with bodies that are not theirs. Bodies that are not welcome on the space on which they operate. Many stories repeat themselves in different bodies and different years, but the pain is one. That pain was injected into bodies that did not choose to exist, but wanted to own that existence. And that pain stays because it is in the blood and it is in the air that we breathe: classist, sexist, racist, unwelcoming. It is something Americans would say is too depressing, but they would still share a tragic news article on Facebook. It is something a Rumi quote cannot heal. I know white people love their translated Rumi, but I only read Darwish. Because I'm always angry. I thought of writing -

The mask has fallen off the mask

I fell down by your side

By your side, pick me up

And hit your enemy with me.

-Mahmoud Darwish, The Mask has Fallen

- on a sign and protesting. But I'm still afraid.

That poem is why I don't want my white friends to ask me if I'm staying safe as Black folks are angry on the streets. Angry at the physical and spiritual exile that doesn't go away by the end of the night or by dispersing the protesters. I'm angry because Americans refuse to see the harm their country has inflicted on the Middle East, and Africa, and Asia, and many other regions. Because the Palestinian genocide is not as infuriating as the discomfort of someone cutting in their Starbucks line. The mask has fallen off faces that voluntarily choose not to see. I'm angry because I wish I were a white American citizen so I could use that privilege to rage freely on the streets. The good white American will meditate about how the negative energy of colored anger doesn't match their new outfit, and they wouldn't pray for our bodies because they don't believe in god. But god is "America." And it is angry and merciless.

***

In 2017, I attended the American Literary Translators Association Conference for the first time. I was suicidal. It was around the time I realized that Americans don't like to listen. 
We know that not all white people are bad allies, but where can we find the good white people? The good white people cannot be ordered on Amazon or made-to-order on Etsy. The protests against criminalizing, murdering, and traumatizing Black bodies has become a Woke Exam to everyone, an exam more available than Covid-19 testing: white and nonwhite, hashtag equality! The good white people are too nice to write anything other than BLM on an Amazon Prime cardboard box delivered by a Black mailman, an essential worker.

That trauma draws the person to the full picture, and that anger can sometimes eat a person up, or gather pieces of a puzzle onto the streets for that anger to manifest.

I and many outcasts in (physical, mental, and spiritual) exile cannot help but see layers of ourselves being peeled off with every tear that mourns Sara Hegazy. Sara was an Egyptian queer activist and communist who raised the rainbow flag at a Mashrou' Leila concert. She was traumatized ever since, until that trauma killed her in mid-June. Sara was a body that dared to show colors, dared to be visible, a mind that dared to speak. It's as simple as that. Voicing and visibility are fatal to the oppressed. She was a soul that dared to be loud: no justice, no peace.

Now ask me: am I safe? I felt Hegazy's short-and-sweet final words very sharply, because I, too, had written that letter in many drafts. I'm sure that letter was not the first draft. It's as recurring and pressing as a landlord who won't stop asking for rent. Even if the dead didn't win the fight, they still fought. And that's worth celebrating their lives and keeping their legacy. Exile is very unkind. No matter how good or smart or Westernized one is, the ghost of home doesn't just stop visiting - the ghost of unwelcome, unloved, un-ok. We poeticize exile in literature classes growing up, and when we're exiled in turn, we can't help but write poetry. Writing in Arabic is a reminder that someone can still pronounce our names, that they might know of the tiny wrinkles in our smiles and ugly cries. How can we ask Sara if she was safe? Do we measure that safety by how many meals were consumed per day? By how much we exercise? By how healthy our Instagram posts are?

The good white people would correct my grammar for my own good, and when I speak well, they'd congratulate me on my colonized English. At ALTA, no one spoke "good English," because none of the good white people congratulate non-native-English-speakers on their language skills. Translators would bend vowels and make up words and it was all good. Academics who praise Black students for being "articulate" would assign these texts with made-up words when relevant, but would never encourage any bended form of English unless that English sips tea with the queen at four pm sharp, walks the dog at five, and plays golf at six. And when it's done, it checks the news, shares a BLM statement, and comes home just in time for dinner.

At ALTA, I recited a Darwish poem with his rhythms and patterns. The audience, mostly translators, were listening intently to a language they didn't understand. But they listened. The Darwish spirit was in the room. That moment kept me alive. It was the closure of my suicidality. 
The culture of silencing is real. Coming to "America" to speak is the funniest joke. My joke still hurts from when an ESL teacher tried to bend the vowels in my throat so I sound like a "native American speaker." This is what Minorities, with a capital $\mathrm{M}$, face from well-meaning white people on a daily basis.

The "you speak good English" was irrelevant in an international space like the ALTA Conference. The times I spoke accented English into the white void of Rochester, NY, where I went to graduate school, the silence was always brutal. And when you fight two opposites - oppression in Arabic, oppression in English, when you face rejection from both sides, what do you do with the silenced body that piles up trauma over trauma?

***

In a scene from the 1994 TV show, My So-Called Life, episode 12, a teacher called a Latinx queer character Enrique. This was followed by a wave of laughter. A white student tossed a scrambled paper at him. To ease that awkwardness, "Rick," the character, sarcastically said in a Latino accent, "Sí, mi nombre es Enrique, and I want to liiive en América." The look on his face showed that this has happened before and will most likely happen again.

I grew up watching the good white people searching for love and solving crimes on TV, and I internalized calling that "American." It is geographically inaccurate to call a part of a strip of land "America," yet the narcissist colonizer would identify as the only American in a vast region carrying different names with accented Englishes, romanticized villages, and fetishized cultures.

I often perceived white people as Americans, The Americans. Only lately did I realize how colonized and white-washed the edited-reality surrounding what I saw as "America" was. Given that I consider myself a linguist, I felt ashamed for overlooking that critical linguistic expression, for overlooking a most obvious flaw. When ethnic minorities call white people "American," they mean anyone who is "not us." They are American; we are diversity. And diversity is easy when it is low-stake and everyone looks happy and pixelated.

In Saudi schools, they used to tell us that Islam is cool because the faithless Americans abandon their children at the age of eighteen. In "America," people don't see their families or care for them like we do. When I was in exile, depressed to the core, drafting suicide notes, I saw how American individualism was selective abandonment. I was alone on every Christmas in the snow, as Americans visited "their" families. Americans look after "their" people. Who is "they?" And who is "we?"

Americans cannot pronounce my name - a name so inconvenient to the American throat. I relinquished that name to make it adaptable, a go-to solution for a smooth interaction with the English-speaking tongue. The middle consonant is what gets lost every time, Zahra. I had a Chinese student named Tommy. When I pronounced his Chinese name, he said, that's my real name. To this day I keep thinking of what is "real" and what is convenient. 
If you are a woman of color surrounded by your powerful tribe, what does it mean to exist in "America" as opposed to the GCC? In 2017, a rich Kuwaiti woman filmed a Black Ethiopian woman, a domestic worker, falling off the top floor. She had held to the edge of the balcony, pleading, "hold me up, hold me up!" The rich woman called her crazy.

And the Ethiopian woman fell down on camera. And she miraculously survived. The rich woman was sentenced to 20 months in prison.

Whiteness is associated to skin color when Black skin is criminalized. But whiteness is a way of behaving: a blank slate that did not endure enough trauma to understand. It is too white, too neat, too fine to be contaminated with the alien concept that there are others who did not have the privilege of a tabula rasa they can color with rainbows and butterflies and basic Instagram captions.

Fighting for injustice is so inconvenient that white people need to schedule it, then implant a "black live matter" sign on their gentrified front yard. Did the people protesting wake up one day and decided it was fun to spit anger at a crowd during a pandemic?

A good white friend was shocked when I told her that what I wanted from life was to be treated like an equal human being. The blank slate couldn't comprehend being deprived from humanity. I felt that hurt in my eyes and in my chest, and it wasn't Covid-19. She posted a black square. For a blank slate to pretend to feel, a select all paint all with one click is so convenient for a C-grade last minute anti-racist homework.

Thank you for submitting your request. We will review your dehumanization at our next diversity panel. Thank you for your patience.

Three weeks prior, another good white friend had given me unsolicited advice: that I must conform to succeed in corporate America. She said if you rebel, nothing happens, do you want the "Egyptian Spring" to happen? The Egyptian spring looked so savage and so foreign. And when the Egyptian spring visited her hometown, she chose the mimosa.

Americans don't like unfamiliar noise. They don't like to listen. With all the teargas and the protest chants, they still don't.

I'm a writer because I'm silenced and I continue to be silenced by different sources with more power than me. On the spectrum of oppression, I have very little power to speak up without having my face smashed. I 
don't exist in my own vacuum of safety, separate from the fight for Black lives. The psychological harm of racism, microaggression, and gaslighting is a continuous brutality that doesn't end when peer and media pressure is gone. I have always talked in the "we" when it comes to oppression. It's always all or nothing. The good white people have the privilege to speak up, or down, or against. But they have it stored in the basement of a three-story house with perfectly mowed lawn. And it is so inconvenient to take it out and dust it.

The highway is blocked by protesters, but the revolution is within a walking distance. In happy neighborhoods, the good white people check solidarity statements as they wait for their brunch to be served. The American spring is blooming in the most painful, most visible, most significant way. A Black man was shot one block away. And the good white people still refuse to see. 